\title{
$\boldsymbol{E}$

2013, Vol. 1, No. 1

\section{Export Platform FDI as a Concept for Growth - Selected Global Experiences}

\author{
Mariusz Omelańczuk
}

\section{A B S TR A C T}

Objective: The main idea presented in the paper is based on the research devoted to interrelations between foreign direct investments (FDI) and export activities that result in the development of the specific form of foreign direct investment - Export Platform (EPFDI).

Research Design \& Methods: The paper is based on literature review. The main body of the paper constitutes the geographical review and the listing of the determinants that influence the decision to launch an EPFDI.
\end{abstract}

Findings: The research brings the working hypothesis that the role of the EPFDI is increasing and free trade zone is a determinant for EPFDI creation.

Implications \& Recommendations: As exports are a GDP component, the issue of export platforms is important from macroeconomic and microeconomic perspective, for politicians and entrepreneurs respectively. The existing literature about EPFDI is limited and calls for growth.

Contribution \& Value Added: The paper constitutes the first review of the EPFDI from a Polish perspective.

\begin{tabular}{|c|c|}
\hline Article type: & literature review \\
\hline Keywords: & $\begin{array}{l}\text { exporting; export platform; FDI; EPFDI; cluster; free trade zone; } \\
\text { free trade area }\end{array}$ \\
\hline JEL codes: & F14, F21, F41, N70, O24 \\
\hline
\end{tabular}

\section{Suggested citation:}

Omelańczuk, M., (2013). 'Export Platform FDI as a Concept for Growth - Selected Global Experiences'. Entrepreneurial Business and Economics Review, 1(1), pp. 91-102. 


\section{INTRODUCTION}

The paper includes basic terms related to the issue of Export Platform (EPFDI) as a specific form of foreign direct investment (FDI). Subsequently it presents examples of previous experience on the various continents: Europe, America and Asia with special focus on Poland. One of the chapters presents key determinants associated with the initiation of activity in the form of Export Platform and the determinants that affect the location of business activity in this form in a specific geographical location. Finally, conclusions and recommendations for further research are suggested.

The main goal of this paper review is related to the specific form of foreign direct investment already defined in some papers as Export Platform Foreign Direct Investment (EPFDI). There is much academic effort dedicated to export, foreign direct investment and in general devoted to globalisation or internationalisation, but there is limited literature devoted to the specific form of foreign direct investment that supports export activity - Export Platforms.

\section{MATERIAL AND METHODS}

According to Sprinz and Wolinsky-Nahmias et al. (2004) the main research methods in international relations are: descriptive (historical) analyses, quantitative, case studies, formal modelling and combinations of the above excluding descriptive. The qualitative (statistical) method is frequently combined with formal modelling. The increasing role of qualitative methods is accompanied by decreasing role of descriptive one. In general the international relations constitute the research area related to broad interactions between countries, societies and organisations. According to the authors the qualitative methods are mainly employed to research trade and there is relatively little research devoted to international finance, FDI, foreign aid. The research method used for the paper is the literature review and the research of descriptive statistics related to Polish exports. It enables to find the introductory findings related to the future research area and assists to find directions for the research including the formulation of working and supporting hypothesis. With reference to the papers that are incorporated in this literature review, it was explored that the majority of authors use quantitative method frequently combined with the modelling. The quantitative method is mainly based on regression analysis. Nevertheless, there are also papers that use descriptive method including literature review.

\section{LITERATURE REVIEW}

Foreign direct investments (FDI) occur in the horizontal form, as market seeking, or vertical form, as resources-seeking, for example natural resources, cheap energy, low cost labour (Helpman \& Krugman, 1985). FDI occur also through Export Platform understood as a venture that is not selling for the local market or to the country of origin of the investors but is dedicated to service third markets (other than country of location and country of investors' origin). Tadesse and Ryan (2005) show examples of the Export Platforms frequently combined with classical forms of foreign direct investments such as horizontal (market-seeking) devoted to service local market or vertical dedicated to utilise cheap local resources. The vertical form (resource-seeking) 
is usually related to the specialisation in the production of specific components, products or production processes. The authors conclude that it is often in practice - a combined model of two or more types of FDI. An example of this combination is the production of components in Ireland by Intel which are exported not only to the US (the country of investors' origin) but also to the customers located in EU countries (in similar quantities). In this specific case we have an example of resources-seeking model combined with Export Platform.

Cholimoniuk-Przeździecka (2011) depicts a new form of foreign direct investment skills-seeking. This is a variation of resources-seeking FDI. Skills are a specific resource more sophisticated in comparison to the natural resources, low-cost labour or low taxes. Another specific characteristic is the nature of these resources - relatively long time of formation by education or training. The emergence of this new form is associated with the development of business services sector in the form of shared service centres. This phenomenon is linked to the rapid development of telecommunications and the Internet.

\section{Determinants}

One of the concepts explaining the advantages of doing business in the form of foreign direct investment is OLI paradigm (ownership, location, internationalization) as suggested by Dunning, Vernon's life cycle theory, Kojima's theory of comparative advantage, Alibera's theory of currency areas and Dunning's theory of economic development (Wawrzyniak, 2010). Chang and Gayle (2009) suggest that the motivation to conduct business in the form of direct investments is to provide better service for the demand of target markets, which may represent significant variability in the time. It enables investors to achieve the minimization of costs related to the optimal response time and change in the risk matrix in terms of risk type as well as weight of the particular risks in their business activity. In particular this applies to the model of Export Platform and horizontal market-seeking FDI. Filatotchev et al. (2001) indicate the issue associated with the acquisition of specific knowledge related to the local market (in the regional or national scale) for example in a different cultural environment (personal communication, priority in personal relations). In the case of the need to acquire such knowledge it is alternatively possible to conclude a long-term agreement with a local partner or establish a local FDI entity, which will be managed by local managers.

Typical factors affecting the location of foreign investment in general are: the size of the market and its potential for growth, the labour cost and its quality (skills), openness of the economy, geographic distance (the specific case is existence of common border), tax rates, political and macroeconomic risks as well as corruption. In the case of investments in the form of Export Platform the most important factor is the free trade zone, which is an element of the openness of the economy. Other factors relevant to the Export Platforms are legal and tax regulations and the institutional environment, which includes the tax system, the mechanisms of the labour market, openness of the economy, political and macroeconomic risks as well as anti-corruption countermeasures. Specific factors that favour Export Platform are industrial clusters and benefits of economy of scale.

Various factors influence the decisions regarding FDI in the form of Export Platforms. Ito (2012) considers free trade zone existence as a decisive factor 
contributing to the decision to invest. On the other hand, Geishecker et al. (2008) define low trade barriers (customs tariffs) as a decisive factor in the choice of the destination country for direct investments in the form of Export Platform. Tomohara and Yokota (2009) also indicate a zone of free trade as a factor that has influence on the strategic decisions made by transnational corporations with respect to location of production units. The factor classified as globalization of the economy represents particular importance for Export Platform. Specific regulations that have influence on the high level of internationalization of the economy affect the success of projects in the form of Export Platform. Nowara (2008) states that political integration of countries into groups results in the increase of foreign direct investment flow, boost effect of investment creation and a small shift effect (relocation of existing investments). The biggest benefits of FDI are achieved by countries that offer favourable economic conditions and a good investment climate. The author observes that in the past two decades the number of agreements establishing free trade zones significantly increased.

Barry (2004) indicates that the factors determining the location of foreign direct investments are the system of tax regulations in the host country (as experienced in Ireland due to competitive tax rates), the system of salaries (Ireland's social partnership model provides an efficient market at relatively low non-wage labour costs) and transparent legal regulations in general. Numerous authors point to Ireland as an example of successful strategy to attract FDI. In 1956 Ireland introduced special preferential tax regulations relating to export sales (Export Profits Tax Relief). Ireland executed the tax policy that provided the lowest corporate tax rates in the European Union (effective tax rate in 1997 was 9.1\%). Moreover, they introduced more favourable regulations for determining the tax base as well as more favourable depreciation rules (accelerated depreciation of fixed assets purchases within investment programs). Barry (2004) defines the shape of tax system in Ireland as a decisive factor that led to the birth of the 'Celtic Tiger'. The author also makes references to significantly decreased number of commercial disputes as a result in the optimised legal regulations, as well as the correct operation of the institutions of justice (courts, chambers conducting arbitration proceedings). Ugur and Ruane (2006) suggest that the direct investments have a positive impact on economic growth if the economy has an appropriate level of openness for bilateral trade, including business support and properly developed financial markets. Barry (2004) also indicates that the optimised public administration is a factor contributing to the increase in the number of foreign investors who implemented the projects in Ireland. The author points out that the local agency responsible for promoting Ireland as the most attractive destination for foreign investments (IDA - Industrial Development Agency) as an important factor affecting the outstanding results in this area. The agency responsible for creating and managing investment climate coordinated long-term efforts to attract industry leaders and "flagship project" that brought decisive contribution for the clusters's creation that constituted the nucleuses of future industrial innovative development. The complex strategy management of the number of issues important at strategic level through various agencies influenced the development of systemic solutions favouring development of foreign direct investment's inflow. These agencies implemented the policy of the Irish Ministry of Labour, Enterprise and Innovation. Considering Ireland's 
achievements it is worth to mention also the other institutions that acted in related areas: County \& City Enterprise Boards (agency that supports micro-enterprises with employment of less than 10 people), Enterprise Ireland (agency dedicated to support the Irish companies at foreign markets), InterTradelreland (agency supporting regional cooperation between small and medium-size enterprises within Ireland). Grosse and Trevino (2005) report that the institutions affecting reduction of uncertainty risk for investments in the destination country have a significant impact on the prospects of attracting foreign direct investments. According to the authors the increased risk for investments is associated with high inflation, unclear regulations, courts' proceedings delays, inefficient judicial system and an inefficient financial system, which Ireland was able to minimize.

Ugur and Ruane (2006) indicate that direct investments in the form of Export Platform frequently take place in clusters which attract multinational corporations in particular. Dietz (1985) indicates that the objective of direct investment is not only to create jobs and generate cash flow for taxation, but also to create amicable environment for interactions between diversified types of entities, in particular participation of local businesses, entities representing different industries as well as science and research units.

Tadesse and Ryan (2005) indicate that the decision related to the location of foreign investment is also based on the estimation regarding potential sales on the local market (or to the country of investor's origin depending on the model of foreign direct investment) and sales to third countries aimed to achieve the optimised scale of production that ensure adequate profitability of the project. Geishecker et al. (2008) shows economy of scale as one of the main factors affecting the development of direct investment in the form of Export Platform.

Tadesse and Ryan (2005) in their article cite the example of the United States' companies that have overseas branches or daughter companies abroad that for the period of $1993-1994$ sold $26 \%$ of production to third countries. Ekholm, Forsild and Markusen (2003) based on data from 1993 to 1994 regarding the sale of FDI located outside of the US in Canada and Mexico, amounted on the local market respectively $54 \%$ and $66 \%$ of production and exported to the US (parent country) respectively $43 \%$ and $31 \%$ (the export sales to third countries was insignificant). Quite different results in terms of sales were achieved by direct investments located in Europe where sales units were located mainly in Ireland, Belgium and the Netherlands. In these countries export sales to third countries (outside the country of incorporation of the parent entity and also outside the local market) amouts respectively to the level of $76 \%, 60 \%$ and $59 \%$ (1993-1994). The US direct investment entities located in Asia exported mainly to the USA and reached, with respect to Singapore and Malaysia, the rates of $50 \%$ and $41 \%$ respectively (1993-1994). In the case of Hong Kong the largest share was $45 \%$ of local sales (exports to the US amounted to 21\%) (1993-1994).

The regional specificity shows the impact of geographical distance between the parent entity and FDI on the preferred type of foreign investment (horizontal marketseeking, vertical resources-seeking, export platform). Tomohara and Yokota (2009) conclude in their paper that the origin of the invested capital plays an important role in relation to the preferred region of its investments. Direct foreign investments carried 
out by the Japanese capital are implemented in Asia, while the US capital is invested mainly in Europe.

The location of a direct investment in the form of Export Platform is also determined by factors such as the intensity of existing bilateral cooperation between the country of the investor and the country of location of the investment as well as the volume of bilateral trade (Markusen 1990). The level of global integration of country for potential investment location, number of existing direct investments, subsidies and preferences for foreign investors, the countermeasures against corruption, interest rates and roads network plays also role for the decisions related to the location of FDI (Kaufmann, Kraay \& Zoido-Lobaton, 1999). Ekholm, Forsild and Markusen (2003) suggest that one of the important factors in the location of direct investment is the prisoner's dilemma. If competition invests in low-cost production location, their competitors will believe that they should do the same.

As noted above, numerous factors influence the location of FDI. Barry (2004) listed in his paper as success factors for Ireland: the agglomeration effect, availability of adequately educated and qualified personnel, the effect of the technology spread in clusters. The author also describes other factors favouring the increase of incoming foreign investments not related to formal regulations: cultural ties, better communication related to the use of the same language (English), fast and efficient transport networks. Good public infrastructure developed thanks to the European Union funds is also indicated as a positive factor. Barry (2004) defines incoming foreign investments as incubators for local entrepreneurs. The studies brought data confirming that many former employees of foreign companies continued their professional activity on their own account. Approximately one third of former employees started own business immediately after the departure. Therefore Ireland serves as leading example of successful FDI management.

\section{RESULTS AND DISCUSSION}

The Export Platform occurs worldwide in America, Europe and Asia. In the consecutive subsections, the main focus is on Europe, thus evidence related to America and Asia is presented as an introduction.

\section{American Experience}

Tadesse and Ryan (2005) present an example of Mexico as a location of Export Platforms type of FDI that are devoted to service the US market as a target market. The authors conclude that Japanese investments in Mexico are oriented to support a larger geographical area than only Mexico. Ekholm, Forsild and Markusen (2003) describe Mexico as a typical example of the investment destination of European companies that want to create a production base supplying the US market (or the entire North American market). After the creation of NAFTA (North American Free Trade Agreement) the inflow of Export Platform FDI is intensified not only in Mexico but also in the second neighbouring country with one of the largest economy in the world, Canada. 


\section{Asian Experience}

Ito (2012) describes Singapore and Hong Kong as Asia's largest recipients of foreign direct investments, in the form of Export Platform, from the USA (the share of exports to the third countries in total sales for the year 2008 amounted to 40-70\%). Ugur and Ruane (2006) wrote about the example of Singapore, a former British colony with cultural similarities in language (English), administration structure, as well as multiplied trade links with the British Empire. The country for decades served as an important regional commercial exchange port. A specific solution observed in Singapore was the promotion of direct investments in the form of joint ventures with the participation of local capital also representing the state, which reserved the influence on strategic decisions and participation in profits, what as a result minimized the duality in terms of the governmental approach to foreign and local companies. Tomohara and Yokota (2009) provide the example of Toyota's strategic decision regarding the relocation of production in the Asian region, which moved specific car brands (Camry, Corolla and Vios) from Indonesian and Philippine' factories to Thailand in the period of 2003 - 2004 as a result of a political decision on the creation of AFTA (ASEAN Free Trade Area). The decision about free trade zone establishment reduced the national strengths and changed the geographical preferences. After free trade zone creation the national custom barriers disappeared and other factors than custom tariffs between the member countries of the free trade zone started to play a more prevailing role. The creation or extension of free trade zone can also result in the industry relocation within the zone.

\section{European Experience}

Tadesse and Ryan (2005) as other authors, report in relation to Europe, that Ireland is a country specialized in the attracting of foreign investments in the form of Export Platform. In Ireland entities representing the direct investments in this specific form executed as average $76 \%$ of export sales to third countries (1993-1994). The Netherlands are the second example, where the export to third countries executed by EPFDI amounted to 59\% (1993-1994) of total sales (the main destination markets were located within the European Union). Tadesse and Ryan (2005) indicate a strengthening trend of the growing interest of investors from Japan in the countries of Central and Eastern Europe as a location of Japanese origin Export Platforms that would service the European Union. Ito (2012) gives the example of Switzerland that hosts many of the tobacco companies. The third example is the Japanese manufacturer of plastic (Vinyl Chloride Monomer), which placed the production in Portugal (there is one production site within EU that supplies all European Union countries).

This author also presents his findings relating to investments made by companies from the US. Most investments of Export Platform type made by the US companies in Europe are located in the UK (the share of exports to third countries in total sales in 2008 amounted to 20-30\%). US investments in the form of Export Platform within Europe took place in the Netherlands, Luxembourg, Ireland, Switzerland and Belgium (share of exports to third countries in total sales for the year 2008 was in these countries within the range 40-70\%).

Ekholm, Forsild and Markusen (2003) are also among the authors who present Ireland as a flagship example of a country where direct investments are carried in the 
form of Export Platform within the European Union. They draw attention to the low production costs as a decisive factor. Tomohara and Yokota (2009) with reference to the European Union also point out the example of Ireland as a country with low tax imposed on legal entities' income and low labour cost in comparison to the EU's averages. However, the authors make the above mentioned conclusion conditional because the extent of final impact of the free trade zone may vary depending on the country or industry. In Ireland the following industries are indicated as examples: office equipment, computing machines, measurement and control equipment, consumer electronics, telecommunication equipment and other electro-machinery and equipment which requires a relatively well- qualified workforce and economy of scale (Barry 2004). In particular, with respect to the products which require economy of scale, the business model of Export Platform was predominant. As a result of such an approach clusters of IT companies (IBM, Intel, HP, Dell, Microsoft) and pharmaceutical companies (Glaxo, Johnson \& Johnson, Pfizer, Merck) were formed in Ireland (Barry 2004). The author shows greater participation of foreign companies in the globalized production processes in Ireland. Foreign companies used 57\% of the components from imports, while export sales had an average share of $92 \%$ in the turnover of the companies, where for comparison the local companies imported only $27 \%$ of the ingredients and their exports achieved an average of only $31 \%$ of sales (2002). Such a situation results in limited competition between foreign investors and local businesses for the reason of diversification of markets; foreign companies deal with outside markets where the local companies service local markets.

With respect to the economic policy Majeed and Ahmad (2006) cite the example of Turkey in the period 1983 - 1990 which changed the structure of exports through incentives for companies, also with foreign capital, in the form of export credits, tax credits, premium support, price stabilisation mechanism (Price Stabilisation Fund), duty-free imports of supplies used for export products' manufacture, exemption from value added tax, grants for foreign trade, exemption from corporate tax as well as export subsidies. These export support instruments attract and favour not only local export oriented production but also the foreign direct investment devoted to export.

\section{Polish Experience}

Geishecker et al. (2008) list the following factors that have influence on the development of export oriented FDI in Poland: low wages, highly skilled workforce, preferential trade agreements which contributed to the creation of manufacturing facilities servicing Western Europe. Poland as the largest country in Central and Eastern Europe is an attractive location for market-seeking horizontal type FDI oriented to service local market (Motta \& Norman, 1996). The authors suggest that Poland within the period 1994-2002 increased exports of finished products due to the presence of direct investments. The Export Platform model proved its important role in Poland within the researched period while the vertical resources-seeking model of FDI, oriented to supply components to the country of origin of the investor, played a minor role in the reported period. The direct investments in the form of Export Platforms were accompanied by contracting of components and services from subcontractors on the local market (outsourcing). Bernaciak and Scepanovic (2010) noted that the southwestern Poland, western Slovakia, the Czech Republic, north-western part of Hungary 
created production clusters of automotive industry. Hardy (2007) notes that Poland, in terms of the international division of labour, in which the decisive role is played by knowledge and innovation, became an exporter of less advanced products in terms of technology as well as basic materials. The reason for such position, despite a welleducated Polish workforce, is low spending on research and development.

On the basis of available data for 2012 (Lista 2000 polskich przedsiębiorstw i eksporterów - ranking Rzeczypospolitej 2013; Lista 500 Polityki - ranking największych polskich firm 2013) we can observe that the group of biggest exporters consist of, in a large part, the entities created as incoming direct investments (from the group of the 100 largest exporters in Poland, 57\% were created as FDI). This population of FDI entities reports the export sales at the level of $77.7 \%$ of total sales on average. The considerable majority (48 entities) of this population (classified as FDI due to at least $10 \%$ foreign stake in capital, defined as power of votes in the authority) achieve from export sales more than $50 \%$ of its income. More than $90 \%$ of revenues from export sales are achieved by 20 largest exporters which are foreign direct investments in Poland. The three largest exporting entities with foreign capital generate respectively $89 \%, 99 \%$ and $91 \%$ of their revenues from export sales. This could mean a significant role in the Polish economy of incoming FDI in the form of Export Platform or hybrid forms of Export Platform combined with vertical resources-seeking model.

Karaszewski et al. (2009) in their study of Polish enterprises revealed that $38 \%$ of investment projects carried out by Polish companies abroad were purely sales supporting, $24 \%$ services oriented, $14.6 \%$ of production and sales nature, $6.8 \%$ sales and services oriented, while only $11.7 \%$ manufacture dedicated (2006-2009). The majority of direct investments made by Polish companies abroad are complementary to export sales. The authors examined the prospects for expansion of Polish companies in the form of foreign investment within the period of 2006-2009: 61\% intend to develop currently held overseas companies and branches, 31\% plan to start operations of new ventures in the form of foreign direct investment abroad. The main directions of expansion are EU-12 countries and other countries of Central and Eastern Europe.

\section{Implications and Recommendations}

In the era of globalization, many companies have operations in several countries. The types of economic relationships are becoming more complex and among others are determined by the specificity of local legislation that create favourable conditions for entrepreneurship or FDI and exports. The increasing availability of advanced telecommunication infrastructure and the increasing popularity of the spreading worldwide mobility, as well as an increase in the share of services in the final value of products, we observe the progressive process of substitution of export sales with more complex forms of satisfying foreign and local demand. Aside from the classic forms of foreign direct investments: horizontal market-seeking or vertical resources-seeking, we have distinguished a growing share of Export Platforms (EPFDI). As indicated by the article, in practice there is domination of hybrid models: horizontal market-seeking combined with the Export Platform (final products), vertical resource-seeking (based on the market research we can define homogenous subgroup: skills-seeking) combined with the Export Platform (components, separated manufacturing or business process). 
While in the area of incoming FDIs in Poland the business model of Export Platform is broadly implemented, the past experience of Polish companies in direct investment abroad shows the use of simple forms of investments such as horizontal market-seeking mainly used as activity complementing exports. With regard to Polish companies investing abroad, the near future may bring an increase in the terms of value of foreign investments in the form of vertical resource-seeking as well as the Export Platform or hybrid forms. Direct investments implemented by Polish entrepreneurs abroad result in the export of capital and the export of demand for labour, which constitute unfavourable consequences for countries with reduced financial resources and high unemployment. This trend may be supported by the relatively lower attractiveness of business environment in Poland (high non-wage labour costs, complicated tax system, complicated law regulations, unstable law regulations, high tax rates, high cost of energy) or the lack of incentives to implement export production. An important stimulant for Polish companies could be to increase the value of the company through the execution of their direct investments abroad and utilisation of cheap resources.

\section{CONCLUSIONS}

The increasing labour cost in China and rising purchasing power of the middle class (domestic demand) in this country can be perceived as factors favouring decisions to make direct investment in one of the ASEAN (Association of South-East Asian Nations) countries in the form of Export Platform. Also the creation of the Customs Union in Belarus, Russia and Kazakhstan may be a stimulant to initiate projects in the form of Export Platform within the new free trade zone. At the same time it should be considered that the enlargement of the European Union may change the status quo, the dynamics and direction of the above described processes.

Globalization processes are reflected in final products, which are assembled from components manufactured in several countries, manufactured in another country and marked with the brand (trademark) of the parent entity (headquarter) of a third country. In addition, identification of origin of added value could be complicated by the issue of transfer pricing broadly practised by multinational corporations.

The Export Platform is not an entirely new form of foreign operations on a global scale but for Polish entities it is the challenge for the future. Due to on-going process of globalization, this form of activity may have increasing importance. The optimized management of the "mix" of exports and direct investments in the form of Export Platform, horizontal market-seeking or vertical resources-seeking, as well as the management of life cycle of projects can play an important role for companies as well as economies as a growth factor.

Based on Zhilin et al. (2006), we can learn more about recent trends in international business research methodologies and this paper brings recommendations related to the future research design. Their paper based on 1296 articles published in six leading international business journals from 1992 to 2003 brings data related to: data collection methods, sample sources including sampled countries and subjects, sampling methods, sample sizes, and response rates. The results of the research are as follows: mail questionnaire surveys dominate, $60.9 \%$ of the studies use a one-country 
sample (88.9\% from western countries), $33.7 \%$ of the studies are based upon sample frames provided by third parties, the median sample size is 180 , an average response rate is $40.1 \%$. The data concerning the countries we can treat as the identification of the niche.

The suggestions for the future research concerns data collection related to the EPFDI's exports to third countries. The data concerning the exports in general is available but the problem is related to identification of the share in the EPFDI's exports that are shipped to countries other than the country of their headquarters. Due to the increasing volume of the international industrial cooperation issue arise concerning the value added measurement or precise estimation due to the transfer prices applied by multinational corporations.

\section{REFERENCES}

Barry, F 2004, 'Export-platform Foreign Direct Investment: The Irish Experience', EIB Papers, vol. 9, pp. 8-37.

Bernaciak, M, Šćepanović, V 2010, 'Challenges of Upgrading: The Dynamics of East Central Europe's Integration into the European Automotive Production Networks', The German Journal of Industrial Relations, vol. 17, no. 2, pp. 123-146.

Chang, Y, Gayle, P 2009, 'Exports versus FDI: do firms use FDI as a mechanism to smooth demand volatility?', Review of World Economics, vol. 145, no. 3, pp. 447-467.

Chilimoniuk-Przeździecka, E 2011, 'Eksport usług biznesowych z Polski', Gospodarka Międzynarodowa - Wyzwania i Nowe Trendy, vol. 179, pp. 45-56.

Dietz, J 1985, 'Export-Enclave Economies, International Corporations, and Development', Journal of Economic Issues, vol. 19, no. 2, pp. 513-522.

Ekholm, K, Forslid, R, Markusen, J 2003, Export-Platform Foreign Direct Investment, National Bureau of Economic Research, Cambridge.

Filatotchev, I, Dyomina, N, Wright, M, Buck, T 2001, 'Effects of Post-Privatization Governance and Strategies on Export Intensity in the Former Soviet Union', Journal of International Business Studies, vol. 32, no. 4, pp. 853-871.

Geishecker, I, Ulff-Moller, J, Pawlik, K 2008, How Important is Export-Platform FDI? Evidence from Multinational Activities in Poland, Working Paper 08-28, University of Aarhus.

Grosse, R, Trevino, R 2005, 'New Institutional Economics and FDI Location in Central and Eastern Europe', Management International Review, vol. 45, no. 2, pp. 123-145.

Hardy, J 2007, 'The New Competition and the New Economy: Poland in the International Division of Labour', Europe-Asia Studies, vol. 59, no. 5, pp. 761-777.

Helpman, E, Krugman, P 1985, Market Structure and Foreign Trade, MIT Press, Cambridge.

Ito, T 2012, Export Platform Foreign Direct Investment: Theory and Evidence, Institute of Developing Economies, Japan.

Karaszewski, W, Jaworek, M, Kuzel, M, Szałucka, M, Szóstek, A, Długołęcka, K 2009, Foreign Direct Investment of Polish Companies: its scale, structure, determinants, influence on the competitiveness, Wydawnictwo Naukowe Mikołaja Kopernika, Toruń.

Kaufmann, D, Kraay, A, Zoido-Lobaton, P 1999, Aggregating Governance Indicators, Policy Research Working Paper No. 2195, World Bank.

Majeed, M, Ahmad, E 2008, 'FDI and Exports in Developing Countries: Theory and Evidence', The Pakistan Development Review, vol. 46, no. 4, pp. 735-750. 
Markusen, J 1990, First Mover Advantage, Blockaded Entry, and the Economics of Uneven Development, Working Paper No. 3284, National Bureau of Economic Research.

Motta, M, Norman, G 1996, 'Does Economic Integration Cause Foreign Direct Investment?', International Economic Review, vol. 37, no. 4, pp. 757-783.

Nowara, W 2008, 'Regionalne porozumienia integracyjne a przepływy bezpośrednich inwestycji zagranicznych', Zeszyty Naukowe, vol. 109, pp. 69-90.

Sprinz, D \& Wolinsky-Nahmias, Y (eds) 2004, Models, numbers, and cases: methods for studying international relations, The University of Michigan Press, United States of America.

Tadesse, B, Ryan, M 2005, 'Export Platforms and the Industry-Specific FDI-Trade Relationship', Journal of Economic Integration, pp. 644-671.

Tomohara, A, Yokota, K 2009, 'Export-led Growth via Export Platform Strategies. The impact of free trade agreements on the structure of FDI', World Economics, vol. 10, no. 4.

Ugur, A, Ruane, F 2006, 'Export Platform FDI and dualistic development', Transnational Corporations, vol. 15 , no. 1 , pp.76-113.

Wawrzyniak, D 2010, 'Determinanty lokalizacji bezpośrednich inwestycji zagranicznych', Gospodarka Narodowa, vol. 4, pp. 89-111.

Zhilin, Y, Xuehua, W, Chenting S 2006, 'A review of research methodologies in international business', International Business Review, no. 15, pp. 601-617.

\section{Author}

\section{Mariusz Omelańczuk}

PhD student in Management and Economics at Warsaw School of Economics (Warsaw, Poland). Master in International Economic Relations (Warsaw School of Economics). The master thesis was devoted to barriers in foreign trade. The research areas of interest include: exports, export business development strategy, internationalisation, export determinants related to financial market.

\section{Correspondence to:}

Mgr Mariusz M. Omelańczuk

Warsaw School of Economics

Building C, Room 3/13 B

Al. Niepodległości 128, 02-554 Warszawa, Poland mariusz.omelanczuk@doktorant.sgh.waw.pl 